\title{
Temas, convenciones y estilos en el diseño de la nueva familia de billetes costarricenses 2009-2019 como expresión de la ideología y la colonialidad
}

Topics, Conventions and Styles in the Design of the New Family of Costa Rican Banknotes 2009-2019 as an Expression of Ideology and Coloniality

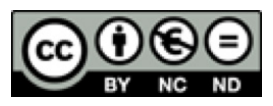

Esta obra está bajo una licencia Creative Commons Reconocimiento-No comercial-Sin Obra Derivada 


\title{
Temas, convenciones y estilos en el diseño de la nueva familia de billetes costarricenses 2009-2019 como expresión de la ideología y la colonialidad
}

\author{
Topics, Conventions and Styles in the Design of the New \\ Family of Costa Rican Banknotes 2009-2019 \\ as an Expression of Ideology and Coloniality
}

\author{
Grettel Andrade Cambronero' \\ Universidad de Costa Rica
}

Costa Rica

Recibido: 09 de marzo de 2019 Aprobado: 17 de julio de 2019

\begin{abstract}
Resumen
El presente artículo analiza los billetes costarricenses como expresión de la ideología y la colonialidad. Se hace una mirada de los estilos y convenciones de antiguas piezas numismáticas costarricenses y también se analiza semióticamente, en torno a esos ejes, el actual papel moneda que circula en Costa Rica, como evidencia de la ideología actual. Sirva este ensayo para dar pie a una reflexión en torno a la relación que existe entre el diseño, la producción visual, la identidad y la ideología.
\end{abstract}

Palabras clave: billetes; ideología; colonialidad; semiótica; convenciones

\begin{abstract}
This article analyzes Costa Rican banknotes as an expression of ideology and coloniality. The styles and conventions of old Costa Rican numismatic pieces are observed in a semiotic analysis around the axes that we mentioned before. Currently banknotes circulating in Costa Rica are evidence of these ideological aspects. This essay is a consideration on the relationship between design, the identity and ideology.
\end{abstract}

keywords: banknotes; ideology; coloniality; semiotics; conventions

1 Profesora Escuela de Artes Plásticas, Universidad de Costa Rica. Máster en Artes por la Universidad de Costa Rica. Correo electrónico: grettel.andrade@ucr.ac.cr

ESCENA. Revista de las artes, 2020, Vol. 79, Núm. 2, pp. 99-125 ISSN 2215-4906 


\section{Introducción}

Una forma de analizar la ideología de un grupo social es dar una mirada a las producciones visuales generadas en esa sociedad: los convencionalismos, los estilos visuales y las temáticas trabajadas se pueden analizar como expresión ideológica. Además, consideramos que, en especial el diseño funcional, utilizado por la población del país en el diario vivir y, más aún, aquellos diseños generados desde el aparato de gobierno manifiestan intencionalmente la ideología. El presente proyecto analizará el diseño de la nueva familia de seis billetes costarricenses emitidos por el Banco Central de Costa Rica (BCCR) desde el año 2009 que se encuentran en funcionamiento actualmente, con los cuales esta última institución:

se enorgullece de [sic] reconocer la obra de seis insignes Beneméritos de la Patria, grandes protagonistas de nuestro sistema democrático, político, económico, educativo y cultural, así como, la riqueza de seis de los ecosistemas que conforman nuestra biodiversidad, que con orgullo preservamos para la humanidad y que convierten a los nuevos billetes con sus hermosas imágenes y coloridos diseños, en algo más que un medio de pago ... son una singular muestra de la riqueza natural que ha colocado a Costa Rica en el mapa mundial como un país en el que la biodiversidad e interés por la naturaleza forma parte de su identidad (Banco Central de Costa Rica, 2013, descripción de video).

La propuesta se da en un país que asume, ya por tradición, la idea de que a la patria la hacen individuos excepcionales, no el pueblo. También retoma el tema, ya antes trabajado, de la biodiversidad, como uno de sus estándares a nivel nacional e internacional, con el que busca pregonar una imagen de uno de los países más ecológicos del mundo (Banco Central de Costa Rica, 2013, descripción de video). En este sentido, el diseño de los billetes forma parte de la imagen marca-país, con todas sus implicaciones ideológicas, que reconoce la importancia del diseño de los billetes, además de ser, también, objetos de colección. El análisis de los billetes que circulan en el territorio costarricense merece ser abordado más allá de ser una ornamentación de un objeto necesario como forma de pago en una sociedad capitalista. Más allá de los árboles, los colibríes y mariposas, como imágenes representativas de la biodiversidad, también contiene representados los próceres de la patria y otros signos. El análisis merece mayor profundidad: ¿cómo se representa esa biodiversidad y esos individuos o signos?, ¿qué implicaciones ideológicas tiene?, ¿qué intención hay detrás de esas imágenes?

La hipótesis de trabajo que impulsa este análisis plantea el diseño de los billetes como expresión de la ideología y, con este ejemplo, se busca reflexionar en torno al diseño funcional en Costa Rica (el diseño gráfico), como expresión del colonialismo cultural. 
La hipótesis específica es que los billetes son uno de los productos de diseño que presentan una mentalidad colonial. Para elaborar esta reflexión, nos valdremos de diferentes herramientas, a manera de aproximación teórica, las cuales consistirán secciones del presente ensayo. En primer lugar, haremos un análisis del término colonialidad desde la imagen que analizamos y con respecto a varios autores latinoamericanos. Luego, abordaremos la sistematización, las convenciones y los estilos presentes en el diseño funcional de billetes, que podrían revelar las convenciones presentes en los estilos de las imágenes utilizadas en los billetes, como forma de normalización o de estructura mental (colonial), en su diseño. La semiótica pierciana será la herramienta que nos permite analizar la forma y el contenido de los billetes que estudiamos en tres ejes: el símbolo, la referencia y el referente. Trataremos de combinar la semiótica pierciana con la colonialidad del poder. Finalmente, (articulado al referente semiótico), reflexionaremos sobre la ideología de la sociedad costarricense actual, como aparato que sostiene la lógica neocolonial de la representación y el diseño de los billetes.

\section{Colonialidad en la imagen Latinoamericana}

El colonialismo se puede entender como "la lógica histórica impuesta por la colonialidad del poder". A su vez, la colonialidad se define como:

contrapartida histórica y no reconocida de la modernidad y de la colonización del Nuevo Mundo, que va desde la función de control ... hasta la noción de la "diferencia colonial" ... una idea que nace a partir de los que ejercen el control sobre el otro pueblo ... un periodo temporal caracterizado por la explotación y conquista de territorios, tiene que ver con la dominación de un pueblo sobre otro (Garrido, 2015, pp. 68-69)².

Como un ejemplo de colonialidad cultural encontramos el referente del Romanticismo europeo, del Barroco y del Neoclásico como estilos que se pueden visualizar en la ilustración científica, los próceres de la patria, los edificios y en los paisajes representados en los billetes costarricenses. En este trabajo se busca explicar cómo, a través de la reproducción de estos estilos, la colonialidad cultural se perpetúa. Por tanto, nuestro proyecto se enmarca dentro de la crítica del poder, en este caso, la influencia del poder cultural eurocéntrico evidenciado en los recursos estilísticos del arte y el diseño en Costa Rica. El macrodiscurso de poder

2 De acuerdo con Rita Segato: "la categoría colonialidad del poder, inicia un modo de subversión epistémica del poder, que es teórica/ética/estética/política, conocida como giro Descolonial” (Segato, 2015, 22-23). La teoría de la colonialidad/decolonialidad del poder fue formulada por el investigador latinoamericano Aníbal Quijano. Este ensayo posiciona el análisis desde una perspectiva decolonial.

ESCENA. Revista de las artes, 2020, Vol. 79, Núm. 2 (enero-junio), pp. 99-125 
europeo ha condicionado, de alguna manera, la forma en la que se enseñan las disciplinas artísticas y el propio ejercicio del arte y el diseño, en una especie de dependencia teórica, académica y práctica, según los modelos asumidos o impuestos por el Viejo Continente ${ }^{3}$.

Los modelos europeos de enseñanza y referentes plásticos que se encuentran presentes en Latinoamérica resultan ser formas de poder que determinan lo que es válido, o no, en la producción artística, pues el macrodiscurso de poder del arte europeo legitima las formas europeas y deslegitima las formas ajenas. Por ejemplo, de forma paradójica, el diseño precolombino se considerara exótico o primitivo. Esto condiciona también la producción y las políticas alrededor de la gestión cultural aceptable, como forma de control, y deslegitima otras formas de producción no académicas, como las prácticas populares que siguen funcionando para el gran público por lograr mayor empatía y con su propia materialidad ${ }^{4}$. El resultado es el sincretismo propio del contexto latinoamericano desde la mentalidad del colonialismo ${ }^{5}$.

\section{Sistematización, convenciones y estilos presentes en el diseño de billetes en Costa Rica: una retrospectiva de los recursos formales y temáticos en la numismática costarricense}

Para analizar los billetes de la serie actual, resulta útil dar una mirada breve a algunos elementos presentes en las colecciones de billetes anteriores con el fin de observar estilos y convenciones en la representación visual presentes en ellos. De acuerdo con José María Castro (2014), los temas de los billetes costarricenses se pueden categorizar en once tipos, que son: alegóricos, científicos y artistas, arquitectónico, agroexportador, grupos minoritarios, biodiversidad, banca privada, costumbristas, símbolo nacional, personaje histórico y prócer de la patria. Analizaremos aquellos billetes costarricenses que consideramos valiosos dentro de los objetivos de este proyecto, al enfatizar en dos tópicos que podemos

${ }^{3}$ Si bien el Diseño Gráfico y las Artes Plásticas tienen funciones diferenciadas, ambas utilizan un universo de recursos en común, todos los que tienen que ver con la imagen: color, forma, composición, estilo. Como evidencia de lo anterior, en la Escuela de Artes Plásticas de la Universidad de Costa Rica, las Artes Plásticas (desde su fundación en 1897) y el Diseño Gráfico (desde 1970) se enseñan en la misma casa de enseñanza y, desde 1972, los cursos básicos de Dibujo y Diseño se imparten de la misma manera para ambas áreas de especialización (Barrionuevo, 1997).

${ }^{4}$ Como ejemplo de diseños populares, se puede revisar la investigación desarrollada por Vargas y Goodfellow (2014).

${ }^{5}$ La Escuela Nacional de Bellas Artes, hoy Escuela de Artes Plásticas de la Universidad de Costa Rica, se orientó en el momento de su fundación por seguir la línea de una academia de corte europeo, tal como lo evidencian Ulloa (2017), Raabe $(2012,2017)$ y Sánchez $(2013,2016)$. 
relacionar con los billetes utilizados en la ideología presente en la época actual, estos son colonialidad y biodiversidad. Así, por estilo entendemos:

la forma constante -y a veces los elementos, cualidades y expresión constantes- del arte de un individuo o grupo ... Por encima de todo, sin embargo, el estilo es un sistema de formas, con cualidad y expresión significativas a través del cual se hace visible la personalidad del artista y la forma de pensar y sentir del grupo (Meyer Schapiro citado por Fernández, 2014, p. 89).

La tendencia a crear y utilizar estilos se refiere, como lo menciona la cita anterior, a las líneas, las formas, las cualidades y la expresión. También, puede vincularse a la técnica utilizada para ejecutar el diseño o a la preferencia por ciertos temas y formas de representación de determinadas imágenes, cuya utilización se hace repetidamente y de forma similar. El estilo se relaciona con momentos históricos y corrientes artísticas, culturas, grupos sociales, ideologías e, incluso, se asocia a simbolismos propios de determinado contexto histórico y cultural.

Con el fin de aclarar el tema de estilo, proporciono al lector un ejemplo breve, que consiste en una descripción de la pintura realizada durante la Edad Media, una época en la que gran parte las representaciones hegemónicas eran religiosas (con una gran influencia de la Iglesia en su realización). En ella, las figuras eran generalmente pintadas por monjes, en libros iluminados o en los murales de las iglesias. Con el afán de enfatizar en la espiritualidad de la representación, en la pintura medieval se eliminaron las representaciones del volumen, pues remitían a lo material, a los deseos de la carne. Las representaciones de las figuras eran más bien hieráticas y frontales. Los personajes se representaban, generalmente, en posiciones similares y haciendo ciertas señas con las manos (como ejemplo de ello la representación del Cristo Pantócrator). Estos gestos simbolizan ciertos contenidos religiosos. En algunos casos, hay marcos de color, que simulan motivos decorativos, los cuales también simbolizan las diferentes esferas: terrestre o celestial, por ejemplo. Ciertos personajes bíblicos, se representaban como animales (los evangelistas como tetramorfos). La jerarquía de los personajes representados se expresaba mediante su tamaño. Se utilizaba mucho color y se concebía la imagen como un recurso para educar o hacer llegar la comprensión de los temas sagrados al pueblo no letrado. Como podemos ver, en la caracterización anterior, en muchos casos, para comprender un estilo se requiere de un conocimiento especializado, que nos permita descifrar las dimensiones y los temas representados (Andrade, 2008b).

El ejemplo anterior resume el estilo de la pintura medieval y, de alguna manera, nos permite comprender que, asociados a los estilos, encontramos generalmente convencionalismos. Es decir, formas de representación que se repiten como los símbolos, los cuales se deben entender como: 
"una cosa que se toma convencionalmente como representación de un concepto"; ambos asuntos: convencionalismos y simbolización están entrelazados, así como forma y contenido constituyen las dos caras de la misma moneda. Este procedimiento o juego con leyes fijadas de antemano, nos recalca los sistemático de su procedimiento. Cuando la sistematización llega a tomar características de notación ${ }^{6}$, o sea, de lenguaje con reglas convencionales propias, para que su código pueda ser ejercido tanto por diferentes artistas, como por sus espectadores, de forma similar a como los juegos tienen sus propias reglas. Por lo tanto, cuando se ha sistematizado la producción artística se puede hablar de convencionalismo (Andrade, 2008a, p. 98).

En el caso que nos ocupa, a partir de la conquista, en Costa Rica y América Latina es complicado hablar de un estilo propio indígena porque el espacio cultural americano, a partir de ese evento, se convierte en un espacio cultural transculturalizado. Una vez que el espacio cultural ocupado por lo que se llama Costa Rica pasa a ser incorporado, como nación, a Occidente, se comienzan a desarrollar prácticas occidentales como la emisión de billetes. Entonces, en los billetes costarricenses, a lo largo de los años, encontramos representados ciertos elementos, como los símbolos patrios, que representan la independencia (cultural, económica y política) del Estado costarricense, o bien, los productos de exportación y la biodiversidad, que simbolizan la riqueza del estado costarricense, motor del desarrollo económico. En algunas épocas, por ejemplo, en los primeros años de independencia, se confirió mucha importancia a los elementos simbólicos relacionados con la creación de una identidad nacional.

En tiempos más recientes, esos elementos han sido sustituidos por aquellos que nos diferencian en la época de la globalización, los cuales simbolizan la fuente de desarrollo económico que, en la actualidad, consiste en una patente preocupación, propia de un país capitalista. Según José María Castro, la historia del papel moneda en Costa Rica se remonta al año 1858, cuando:

los gobiernos de las jóvenes Repúblicas de Centroamérica emplean a los estados desarrollados para producir papel moneda propio, sobre todo en Inglaterra y los Estados Unidos ... Costa Rica en particular compraba los diseños preestablecidos de casas fabricantes y en ocasiones encargaba los diseños según parámetros establecidos por el gobierno de turno (Castro, 2014, p. 4).

${ }^{6}$ (Zapelli, 2003).

ESCENA. Revista de las artes, 2020, Vol. 79, Núm. 2 (enero-junio), pp. 99-125 

costarricenses 2009-2019, como expresión de ideología y colonialidad

Según este autor, el diseño de los billetes emitidos entre 1858 y 1936 plantea el interés de las clases dominantes de Costa Rica por construir una imagen del estado costarricense y la identidad nacional, alrededor del Estado liberal. Esto se evidencia en la ponencia "Iconografía, alegorías, imágenes e identidad nacional: los billetes de Costa Rica y el ideal de progreso liberal (1858-1936)", ofrecida por Ronny J. Viales y Manuel Chacón Hidalgo, en el VI Congreso Centroamericano de Historia, celebrado en Panamá en julio de 2002. En esta, "se plantea la emisión de valores como un medio de propaganda más del estado” (Castro, 2014, p. 20).

Indagar en la historia del papel moneda es importante, pues nos revela que, en muchos casos, los estilos están relacionados con las condiciones de producción de los diseños. Si los primeros billetes se enviaban a imprimir en Europa y los Estados Unidos con modelos preestablecidos, propios del país donde se imprimían, es evidente que encontraremos en el estilo de los mismos una representación colonial, que era la que imperaba en ese lugar y momento histórico. En los proyectos posteriores, se mantuvo el estilo europeo producto de la tradición y de la mentalidad colonial. En este sentido, nos podemos plantear ciertas preguntas: al desarrollarse en América ¿también acaban los estilos europeos, por convertirse en americanos? Consideramos que, se debe analizar el estilo, sus elementos y la sociedad en la que se producen, para determinar si hay, o no, una imposición del estilo. Un estilo, para que sea propio, nace de un lugar y de un, o unos, individuos particulares, cuyas características se encuentran determinadas, como mencionaba la cita anterior, como un medio "a través del cual se hace visible la personalidad del artista y la forma de pensar y sentir del grupo" (Meyer Schapiro citado por Fernández, 2014, p. 89).

En este sentido, el grupo social en el que un diseño es producido posee una identidad cultural propia, producto de su historia. En el caso de Costa Rica, al hablar de identidad, nos deberíamos referir a las identidades que han pasado por un caminar histórico de llegada al país: vida y mestizaje. Podríamos discernir la población proveniente de América precolombina indígena (población originaria) y la que ha llegado, desde diferentes regiones del mundo en diferentes momentos históricos: Europa (desde el periodo colonial), las poblaciones de origen chino, la población negra (proveniente de África y del Caribe), entre otras. Asimismo, en los procesos de colonización pueden suceder diferentes fenómenos: se puede dar la imposición de los estilos; la absorción de estos, por parte del grupo; un proceso de transculturación, que supondría una mezcla de estilos propios y los del colonizador; o bien, la conservación de los estilos propios que, en el contexto del proceso colonizatorio podría implicar, o no, formas de resistencia por parte del grupo colonizado. Analizar los estilos es una forma de comprender la historia y la identidad de un pueblo, la colonización, si la hubiera, y las características particulares de ese proceso, que vienen a ser parte de la historia de esa comunidad?

\footnotetext{
7 Autores de referencia que han estudiado casos específicos alrededor de la temática, antes o
} 
En el papel moneda costarricense encontramos, entonces, el uso de recursos clásicos europeos utilizados en la representación académica, tendencias estilísticas del arte plástico del Barroco, del Neoclásico y del Romanticismo europeo. Estos estilos se caracterizan por su interés en retomar la estética del clasicismo grecorromano, desarrollada durante el Renacimiento. Épocas caracterizadas por el interés en la representación del mundo natural: la figura humana, la arquitectura, el mundo natural. En este sentido, se retoman los recursos formales que posibilitan la representación del volumen y la perspectiva. Estos elementos los podemos encontrar presentes en los billetes en la trama lineal, que proporciona la ilusión de volumen, luz y sombra de los diferentes elementos temáticos representados. Además, se retoman elementos decorativos característicos de herencia europea grecorromana, caracterizados por la simetría, el equilibrio y la armonía. Asimismo, en la estética del estilo Barroco encontramos "la suntuosidad, el primor, la hermosura, lo pulido, la valentía, el lucimiento, lo costoso y la riqueza" (Justino Fernández citado por Fernández, 2014, p. 94). Estos valores los podemos encontrar

Imagen 1. Capitel de columna estilo corintio, decorado con acantos. Teatro Nacional de Costa Rica, 1897

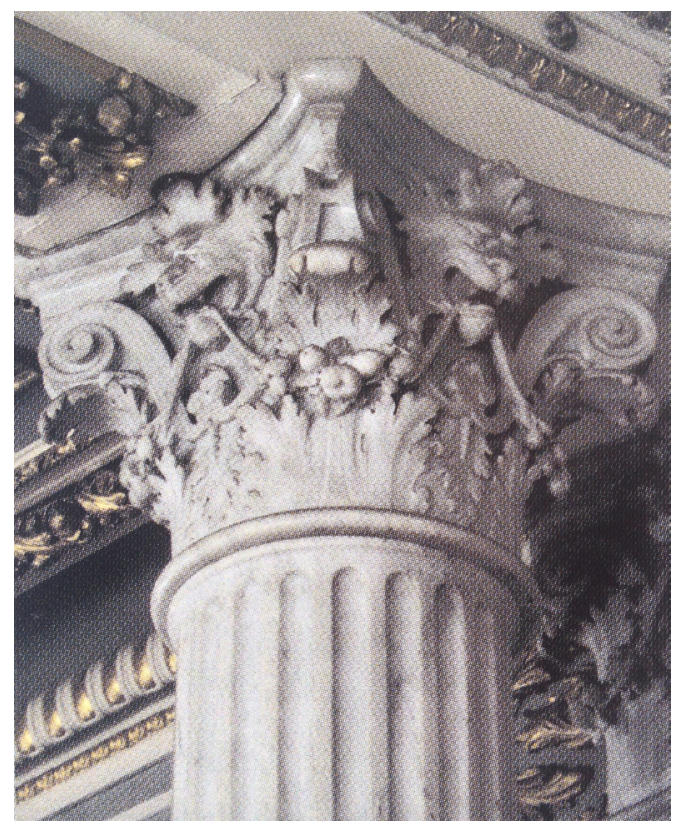

Fuente:Vargas, Gómez \& Chacón (2009). en ciertos componentes suntuosos utilizados como elementos decorativos y en la composición del papel moneda en Costa Rica.

Por otro lado, en Costa Rica la idea de la modernidad o ser moderno, durante la colonia, era parecerse o imitar a España. Luego de la independencia, ser moderno era parecerse a Francia, pues ese era el modelo de la oligarquía cafetalera. Esto se evidencia en el gusto arquitectónico, por ejemplo, los materiales y estilo del Teatro Nacional de Costa Rica (Oviedo \& Santamaría, 2015) y la moda utilizada por las élites gobernantes en esa época (Hurtado, 2017). Coherentemente con lo anterior, se encuentra el diseño de los billetes. A continuación, analizaremos algunos casos (existen muchos más), con lo que buscamos una manera de ejemplificar la utilización de elementos decorativos europeos. Los estilos europeos del Barroco, del Neoclásico y del Romanticismo se encuentran en los billetes en forma de elementos utilizados en la arquitectura

después de la colonización, y la transculturación en las imágenes: Parkinson (2011); Gruzinski (1991; 1994); Spitta (1995); Hill (2010) y Segre (2007). 

costarricenses 2009-2019, como expresión de ideología y colonialidad

Imagen 2. Diseño del billete de 500 colones, emisión de 1979-1985. (Se reproduce una edición especial conmemorativa, emitida con el mismo diseño en 1994)

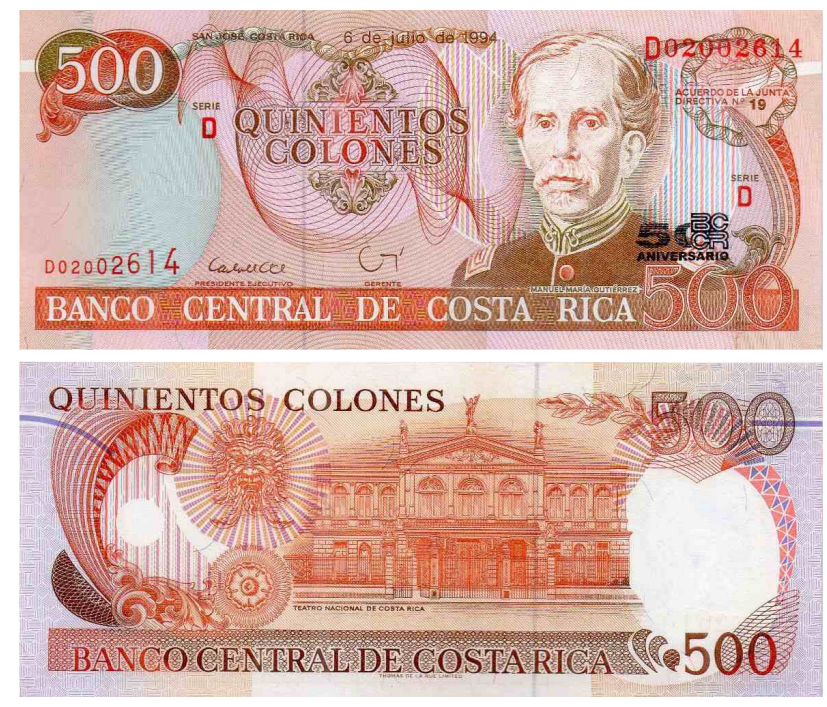

Fuente:Colnet

clásica europea como la hoja de acanto, frecuentemente visualizada en las columnas en el capitel de estilo corintio (Imagen 1). Este mismo motivo se puede visualizar en el billete de 500 colones (Imagen 2) y en el billete de 5 colones (Imagen 4) 8 .

La hoja de acanto fue incorporada desde el siglo $\mathrm{V}$ por el arquitecto griego Calímaco (Vargas, 2009, p. 19). En estos billetes de 500 y de 5 colones, se adopta la hoja de acanto al estilo del viejo continente. Podemos observar, de esta manera, la legitimación de recursos visuales o estilos, por ser importados del continente europeo y transportados al diseño funcional de billetes costarricenses, lo cual, sin duda alguna, es una actitud propia de una mentalidad colonial, un ejemplo estilístico de la colonialidad del poder. El uso de la hoja de acanto, se relaciona con las artes y el amor por ellas ${ }^{9}$. En el billete de 500 colones (Imagen 2), se puede observar la hoja de acanto en el anverso, en ambas esquinas, junto al número 500 y a las palabras "quinientos colones". En el reverso del billete, se puede observar, de nuevo, la hoja de acanto sobre la frase "Banco Central de Costa Rica". Además, podemos notar cómo se destaca la arquitectura de influencia europea, como lo es el Teatro Nacional, que contiene capiteles decorados con acantos (Imagen 1).

Al igual que el acanto, el uso de recursos figurativos en otros billetes y monedas, remitía a la lógica simbólica de los elementos vegetales y animales, que, a su vez, relacionaba estas plantas con ciertos valores deseables. Por ejemplo, el uso de coronas de mirto en las monedas de cinco céntimos (Imagen 3), acuñadas desde 1864 hasta 1951, remitían al símbolo de la paz (Vargas, 2009, p. 17). En otros billetes costarricenses encontramos la hoja

8 Retomar estos estilos europeos parece ser una tendencia en la Latinoamérica colonial, tal como lo nota Silvia Fernández en su estudio acerca de las portadas de libros desde 1777 hasta 1850 en México.

9 Su uso se encuentra asociado a una leyenda, supuestamente narrada por Vitrubio. Etimología de acanto. Recuperado de: http://etimologias. dechile.net/?acanto Basado en libro IV, capítulo I, del texto De architectura, de Vitrubio.

ESCENA. Revista de las artes, 2020, Vol. 79, Núm. 2 (enero-junio), pp. 99-125 
de laurel, lo cual indica que el personaje representado es laureado. Por su parte, la rama de encino es símbolo de la libertad.

Imagen 3. Moneda de cinco céntimos, 1951

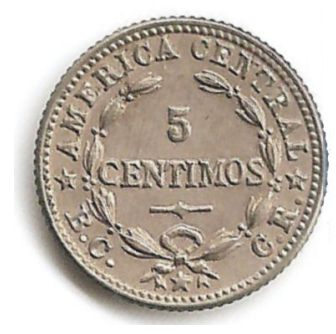

Fuente: Ucoin.
Imagen 4. Diseño del billete de cinco colones, 1968-1992

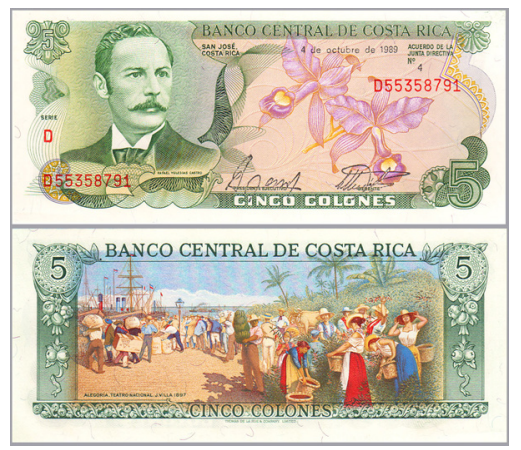

Fuente: Colnet.
Imagen 5. Moneda de un colón

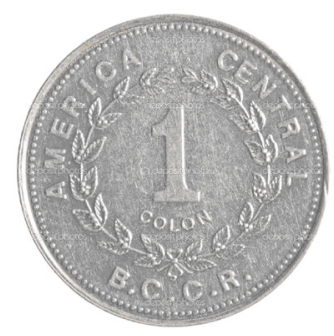

Fuente: Depositphoto.

A partir de 1847, se empieza a utilizar en la numismática el tema del café (el cultivo, la rama, la flor y el fruto), debido a la importancia de este como producto de exportación. La temática la podemos visualizar, claramente, en reverso del billete de cinco colones (Imagen 4),

Imagen 6. Moneda de 100 colones, 1995

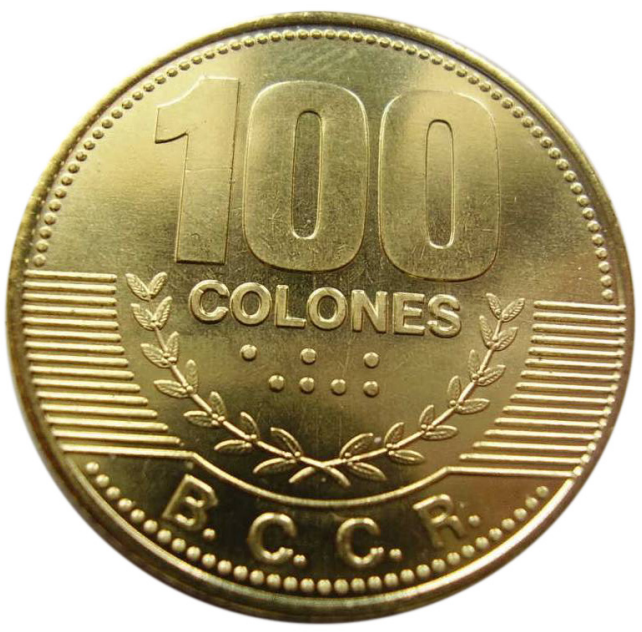

Fuente:Depositphoto también en la moneda de un colón (Imagen 5) y de 100 colones (Imagen 6). En este sentido, encontramos un giro de la lógica meramente estética, para resaltar la importancia de aquellos motivos que tienen una importancia económica (fundamentada en la lógica capitalista), considerada deseable para el bienestar de la nación. Según Castro:

En el imaginario del conglomerado existe la idea de cohesión bajo principios de identidad común o identidad cultural del Estado y nación, para reforzar esto resulta imprescindible la construcción de símbolos patrios que refuercen de alguna medida la personalidad del Estado y su validación como nación soberana e independiente (Castro, 2014, p. 31). 

costarricenses 2009-2019, como expresión de ideología y colonialidad

Asimismo, en el billete de cinco colones encontramos, también, la guaria morada: flor nacional. Un elemento botánico presente en el paisaje que, a la vez, es un símbolo patrio de la identidad del pueblo costarricense. La imagen, en este sentido, es un símbolo identitario nacionalista y representa, de alguna manera, una temática propia que, de una forma u otra, se aleja de los referentes europeos mencionados anteriormente. Aunque, en el fondo, su estilo sigue siendo europeo en su preocupación por la representación científica del volumen y la trama.

Es necesario destacar que, a inicios del siglo XX, el arte precolombino o indigenista, en Costa Rica, fue anulado y menospreciado desde la óptica europea ${ }^{10}$ (Montero, 2015, pp. 42-45). No solo debido a que es producto de la cultura colonizada, la cual fue subyugada y tratada como inferior desde la lógica de la otredad, sino que, además, el arte indigenista fue considerado como un conjunto de objetos arqueológicos y extraños desde la óptica europea. En la academia de arte en Latinoamérica, debido a la influencia del arte europeo, los estilos propios de este continente se impusieron como "buen diseño", "equilibrado" y "armonioso". Es este sentido, la mirada hacia el arte precolombino, a finales del siglo XIX e inicios del siglo XX, se da con la extrañeza y el exotismo de quien mira al otro, pues no se concebía lo indígena como una identidad propia del "ser costarricense" (Molina, 2005; Ferrero, 2004 y Solórzano, 2017). En la mayor parte de los billetes anteriores a la década de 1991, encontramos poca presencia del motivo precolombino como tema central (6 billetes del total de los emitidos por el BCCR, antes del año 2008). Los cuales reproducimos a continuación (Imágenes 7 a la 12):

Imagen 7. Billete de 10 colones. Banco Nacional de Costa Rica, Serie F, 1941

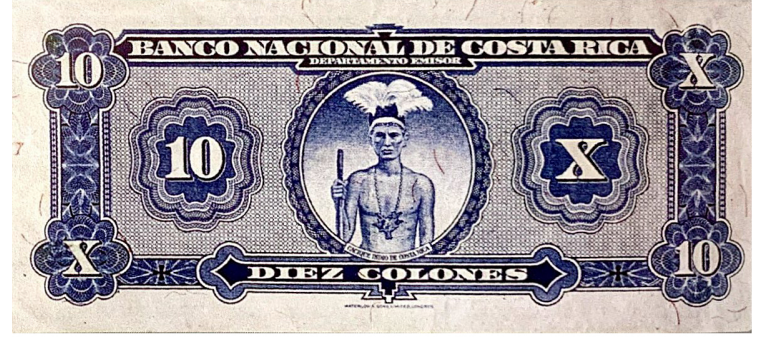

Fuente:Carranza (2012).
Imagen 8. Billete de 100 colones. Banco Nacional de Costa Rica, Serie F, 1942

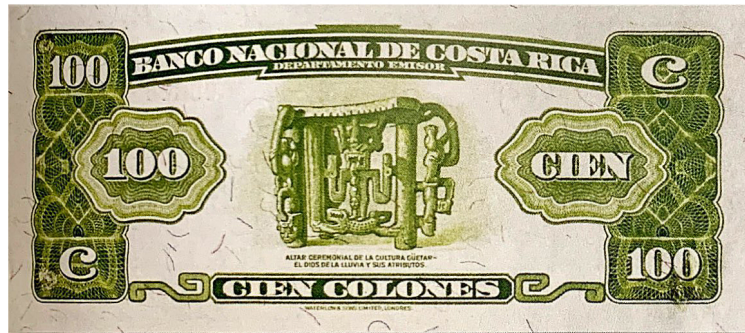

Fuente: Carranza (2012).

${ }^{10}$ Este hecho se puede contrastar con el caso de México, donde es posible que, debido al discurso indigenista, el arte precolombino quedara incorporado en los billetes mexicanos desde las primeras décadas del siglo $X X$. 
El elemento temático precolombino se retoma en el billete de 5000 colones (Imagen 12), en el que se diseña un conjunto de biodiversidad y arte indígena, al recuperar en el diseño dos estatuillas precolombinas de oro y piedra, así como una esfera. Además, se retoma el recurso en los elementos decorativos presentes en las esquinas del billete. Cabe destacar que este billete, al igual que el de cinco colones, rompe con la simetría tradicional del diseño europeo, lo cual resulta también un recurso novedoso.

Imagen 9. Billete de 100 colones. Banco Nacional de Costa Rica, Serie F, 1942

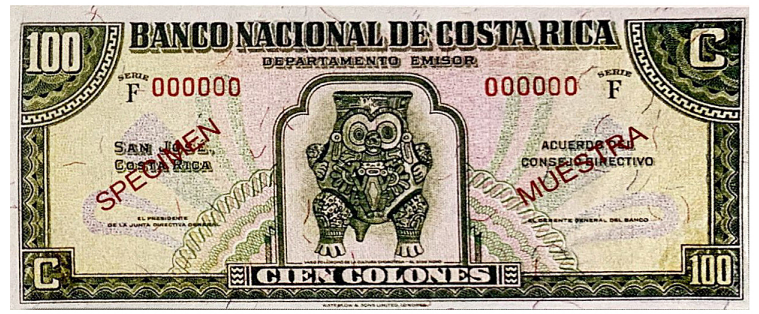

Fuente:Carranza (2012).

Imagen 11. Billete de 50 colones. Banco Internacional de Costa Rica, Serie E, 1933. Muestra un metate o piedra de moler precolombina.41

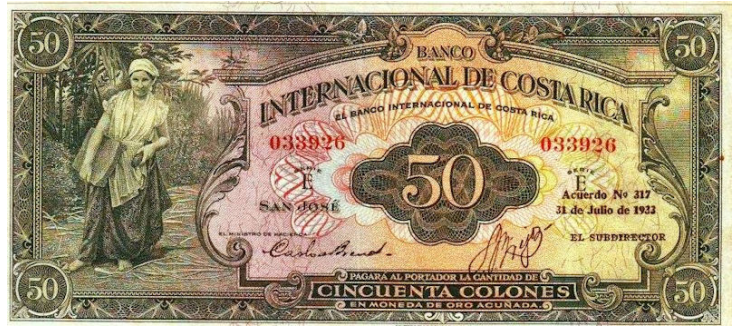

Fuente: Carranza, (2012).
Imagen 10. Billete de dos colones, Banco Nacional de Costa Rica, Serie E, 1941

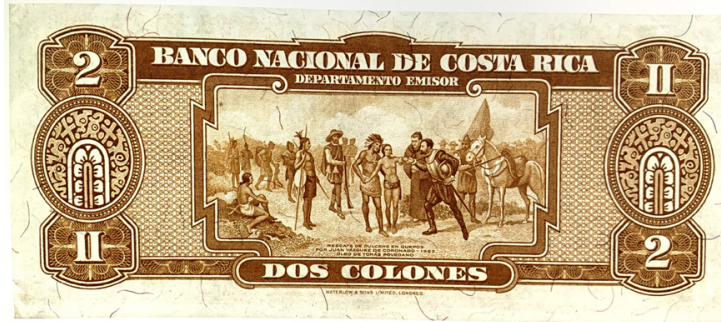

Fuente: Chacón, (2016).

Imagen 12. Billete de 5000 colones, Serie C, 1991-2008
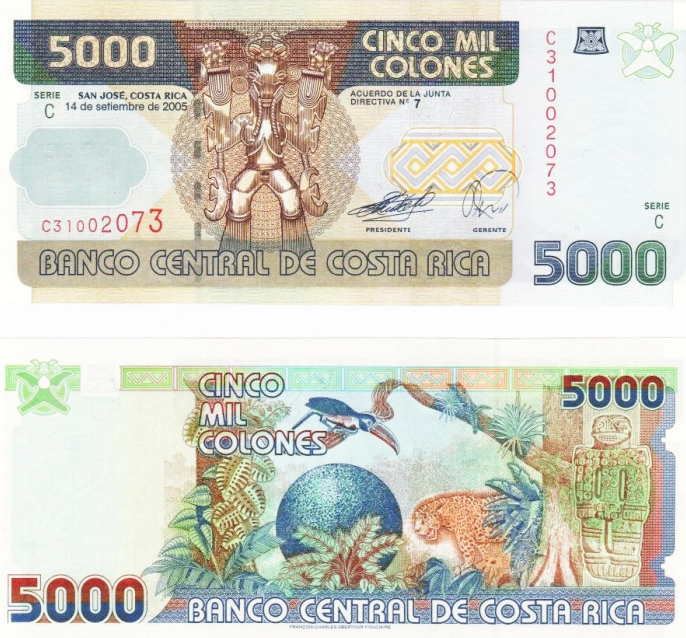

Fuente: Banco Central de Costa Rica, billetes retirados de circulación. 
Como hemos podido analizar, anterior a la colección de billetes actual encontramos destacados motivos académicos europeos y elementos que enfatizan una visión identitaria nacionalista como la orquídea y el café, principal producto de exportación. Por su parte, el billete de 5000 colones (Imagen 12) rescata los tesoros indígenas desde una óptica arqueológica. Sin embargo, aunque sean referentes locales, en muchos casos, el estilo de representación retoma los recursos de la trama y el volumen propios del lenguaje europeo y la aculturación criolla, en el proceso colonial. También la forma en la que se maneja la temática es desde una mirada colonial moderna, una que aprecia la diferencia de lo exótico; la naturaleza que es explotada.

En la actualidad, la lógica a la que remite la colección de billetes que nos proponemos analizar en la nueva familia de billetes costarricenses continúa con la tradición sostenida en la emisión de billetes anterior a la actual, ejemplificada con los billetes de 2000 y 10 000 colones (imágenes 13 y 14). En el reverso se destacan los recursos naturales de flora y fauna que nos representan por su importancia como factor de crecimiento económico. La biodiversidad, motor del turismo, se ejemplifica en la riqueza del territorio costarricense, las especies animales y vegetales características de los diferentes hábitats naturales.

Imagen 13. Anverso y reverso del billete de 2 000 colones. Serie A, 1997-2008
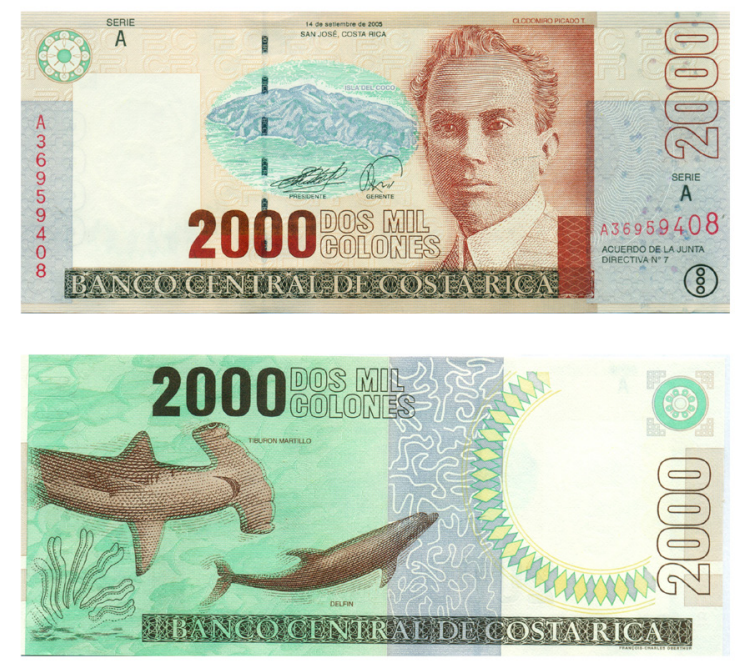

Fuente: Banco Central de Costa Rica, billetes retirados de circulación.
Imagen 14. Anverso y reverso del billete de 10 000 colones. Serie A, 1997-2008

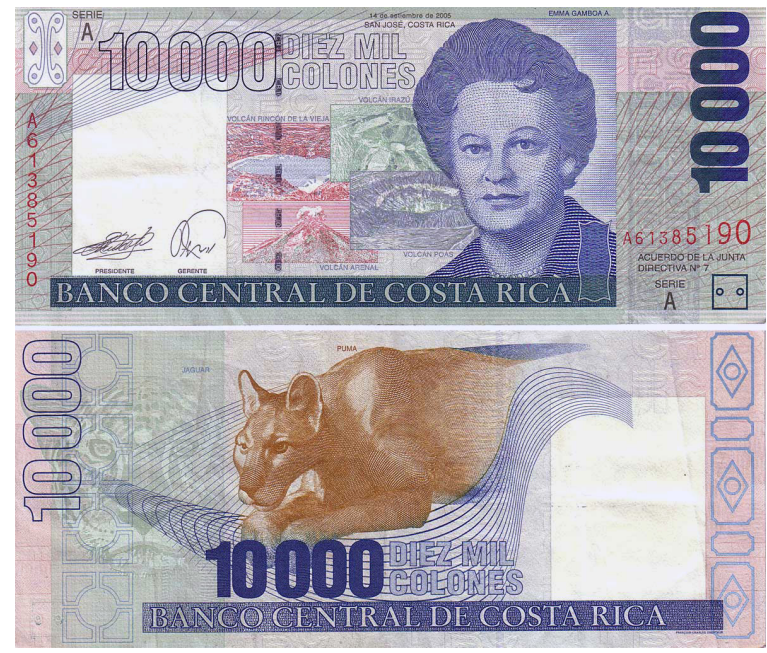

Fuente: Banco Central de Costa Rica, billetes retirados de circulación.

Con una visión aún más conservadora, en el anverso se representan próceres de la patria y elementos naturales, históricos, arquitectónicos y culturales propios de la historia 
de Costa Rica. El estilo compositivo es mucho más moderno que el de billetes anteriores, al rescatar el uso de los blancos (cuya finalidad es la visualización de recursos de seguridad como la marca de agua), y -aunque con menor presencia y tamaño- recursos ornamentales más indigenistas.

Si bien en los billetes de circulación actual, que analizaremos más adelante, se representa el motivo natural y el indígena (presente en los sellos), nuestra siguiente hipótesis de trabajo es ¿encontramos cierta mirada exótica presente en los temas representados en los billetes? ¿Es un exotismo con que se mira lo que somos? ¿Es la imagen que se promueve en el propio territorio costarricense, una mirada turística europea? ¿Se promociona al país con los billetes, como destino único y especial, por el gran atractivo de su biodiversidad? ¿Representan estos billetes las identidades que conforman el ser costarricense?

\section{Nueva familia de billetes costarricenses, Serie A, 2009-2019}

\section{Herramientas semióticas para el análisis de billetes}

En los billetes que nos proponemos analizar, encontramos elementos como personajes, edificios, biodiversidad y sellos precolombinos. Podemos estudiar estos signos visuales desde la semiótica, que funcionará como herramienta de análisis. Hemos descartado el análisis de elementos como la tipografía, el color y los recursos de seguridad, pues no contribuyen a alcanzar el objetivo de la investigación. La disciplina semiótica estudia la producción de sentido de los signos (entre ellos los visuales, las imágenes) y el análisis de las significaciones. Existen tres niveles desde los cuales se puede analizar el objeto comunicacional: en primer lugar, el nivel sintáctico, el cual trabaja la gramática, la forma. En segundo lugar, el nivel semántico, que estudia el significado o contenido. Finalmente, el nivel pragmático del lenguaje, que enfatiza el elemento social del desarrollo de este; también es importante para su estudio y determina, en gran medida, su uso.

Al seguir la propuesta hecha por Charles Sanders Pierce, consideramos la semiosis como un proceso lógico de estímulo-respuesta (en términos de comportamiento). En este sentido, entendemos el signo como algo que está en lugar de alguna otra cosa o que representa otra cosa y es comprendido o interpretado por alguien, esto es, que tiene un significado para alguien. De acuerdo con Pierce, el signo está constituido por un modelo tríadico: el símbolo (significante o -en términos piercianos- "representamen"), que llamaremos plano sintáctico del signo, consiste en los aspectos formales del signo. La referencia (significado, o -en términos piercianos- el "interpretante") aborda el plano semántico del signo o de contenido. El referente (la realidad denotada, -en términos piercianos- el "objeto"), este es el plano pragmático del signo, los aspectos sociales o culturales en los cuales el signo existe o funciona. Resulta 
necesario aclarar que, el término "símbolo" utilizado por Pierce no se relaciona con el abordaje que hemos hecho del término signo, descrito en páginas anteriores. Por lo que a este plano lo llamaremos "plano sintáctico".

\section{Plano sintáctico general de toda la colección de billetes}

Nos referiremos a aquellos aspectos que consideramos relacionados con ideología y colonialidad. Se dejará de lado los que no aportan mucho a los objetivos de la investigación. El estilo como presentación del volumen y la trama en el personaje está presente en el anverso de los billetes y también en el reverso, en el paisaje representado y los elementos de flora y fauna. Este recurso remite a la ilustración científica, al utilizar recursos estilísticos y convencionales propios del academicismo europeo. De manera que, ciertamente, remiten a una representación colonial europea. Como aspectos novedosos que encontramos, con respecto a pasadas colecciones de billetes, a nivel de diseño, se encuentran: el uso de planos de color en algunos elementos más pequeños. Este es un elemento que se retoma de pasadas colecciones de billetes (como el de 5000 colones, que fue analizado con anterioridad). Uso de tipografía (numérico y letras) tipo palo seco (sin serifas o ribetes en las terminaciones). En lo compositivo se retoma el diseño compositivo asimétrico, reservando espacios blancos.

\section{Plano semántico general:}

- Convenciones anverso: representación de los próceres de la patria, tradicionalmente presentados en los billetes costarricenses.

- Convenciones reverso: representación de la biodiversidad costarricense, tradicionalmente mostrada en los billetes costarricenses. Sello precolombino, como recurso de seguridad impreso con tinta iridiscente.

\section{El billete de 1000 colones:}

- Anverso. Plano semántico. Personaje: Braulio Carrillo Colina. Motivo principal: Escudo del Estado de Costa Rica.

- Reverso. Plano sintáctico. Ecosistema: bosque Seco. Especies destacadas: árbol de Guanacaste, Pitahaya y el Venado Cola Blanca. Otros motivos ornamentales: escorpión. 
Imagen 15. Anverso del billete de 1000 colones

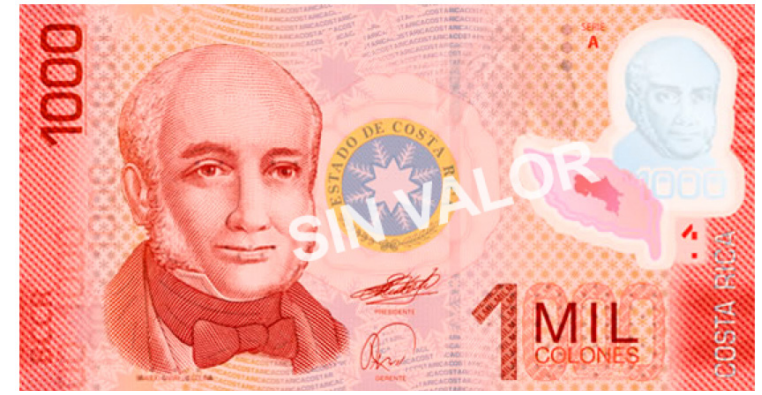

Fuente: Banco Central de Costa Rica, billetes en circulación.
Imagen 16. Reverso del billete de 1000 colones

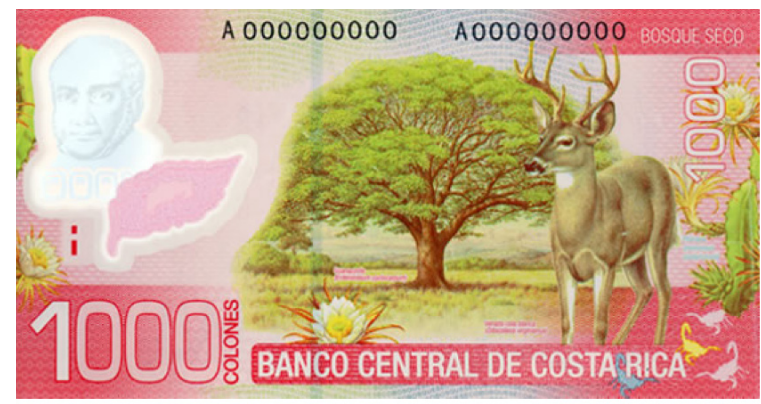

Fuente: Banco Central de Costa Rica, billetes en circulación.

\section{Billete de 2000 colones}

- Anverso. Plano semántico. Personaje: Mauro Fernández Acuña. Motivo: Colegio Superior de Señoritas.

- Reverso. Plano semántico. Ecosistema destacado, Arrecife de coral. Especies destacadas: tiburón toro, estrella de mar y plumas de mar. Otros motivos ornamentales: tortuga marina.

Imagen 17. Anverso del billete de 2000 colones

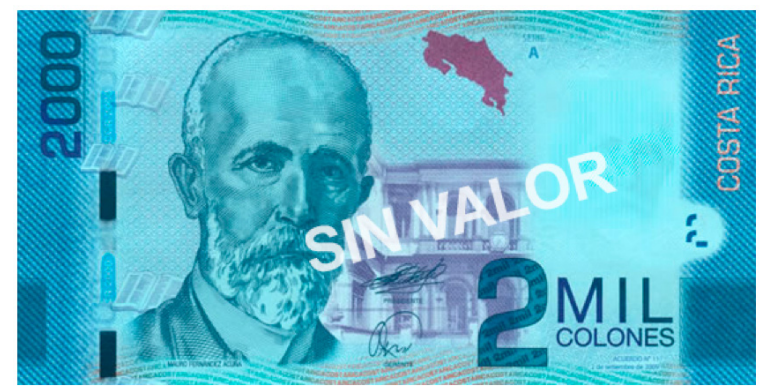

Fuente: Banco Central de Costa Rica, billetes en circulación.
Imagen 18. Reverso del billete de 2000 colones

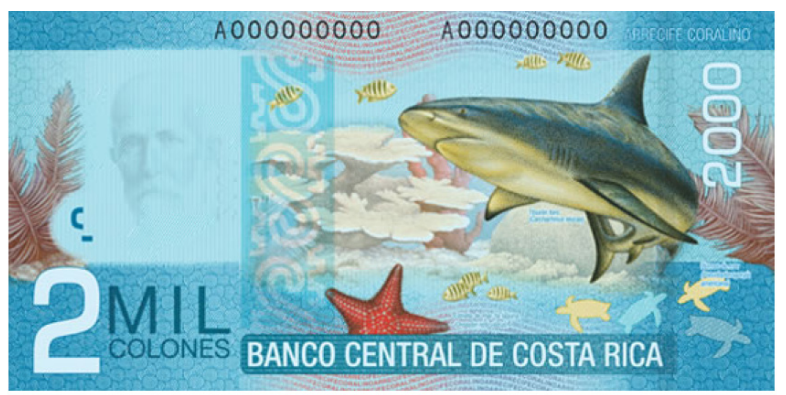

Fuente: Banco Central de Costa Rica, billetes en circulación.

\section{Billete de 5000 colones}

- Anverso. Plano semántico. Personaje: Alfredo González Flores. Motivo: Banco Internacional.

- Reverso. Plano semántico. Ecosistema: manglar. Especies destacadas: mono 
carablanca, mangle colorado, cangrejo marinera. Otros motivos ornamentales: cocodrilo.

Imagen 19. Anverso del billete de 5000 colones

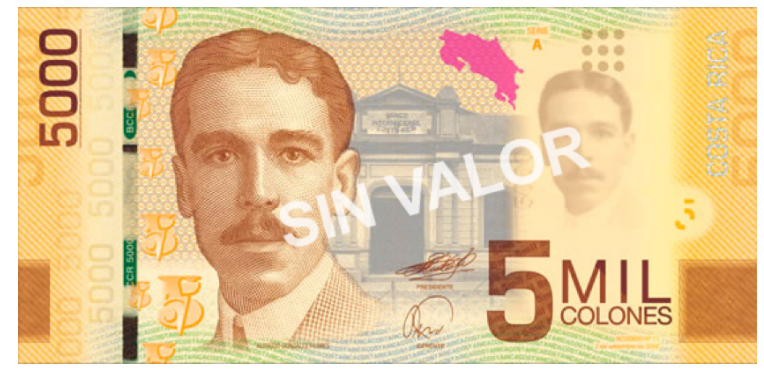

Fuente: Banco Central de Costa Rica, billetes en circulación.
Imagen 20. Reverso del billete de 5000 colones

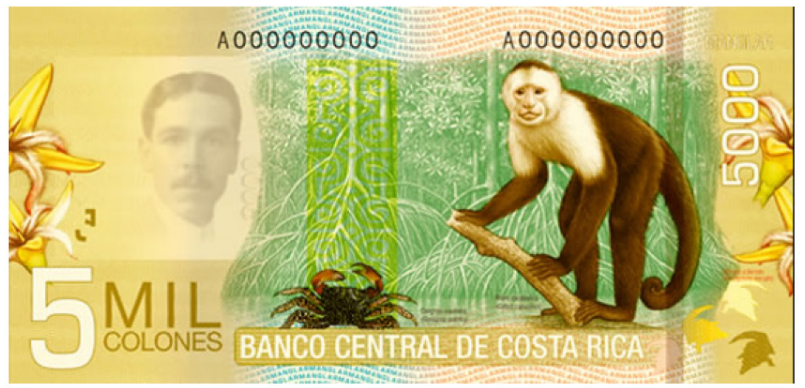

Fuente: Banco Central de Costa Rica, billetes en circulación.

\section{Billete de 10000 colones}

- Anverso. Plano semántico. Personaje: José Figueres Ferrer. Motivo: Abolición del ejército.

- Reverso. Plano semántico. Ecosistema destacado: bosque lluvioso. Especies destacadas: perezoso de tres dedos, orquídea hongo copa. Otros motivos ornamentales: flores.

Imagen 21. Anverso del billete de 10000 colones

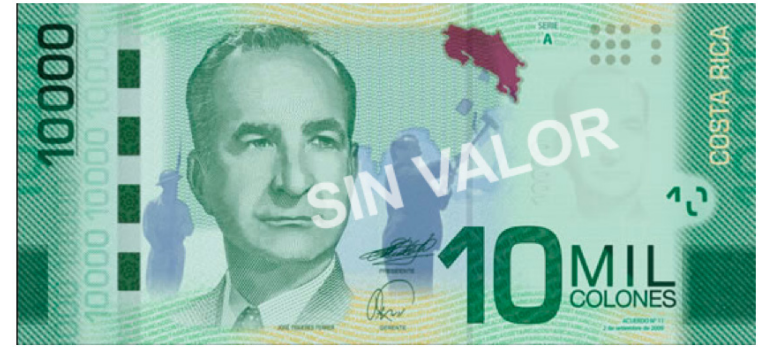

Fuente: Banco Central de Costa Rica, billetes en circulación.
Imagen 22. Reverso del billete de 10000 colones

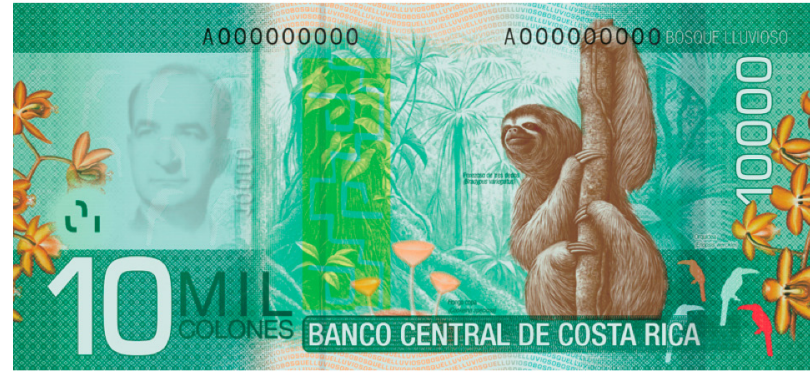

Fuente: Banco Central de Costa Rica, billetes en circulación. 


\section{Billete de 20000 colones}

- Anverso. Plano semántico. Personaje destacado: María Isabel Carvajal "Carmen Lyra". Motivo: ilustraciones cuentos de mi tía Panchita.

- Reverso. Plano semántico. Ecosistema destacado: páramo. Especies destacadas: colibrí chispita, hierba o papelillo. Otros motivos ornamentales: conejo.

Imagen 23. Anverso del billete de 20000 colones

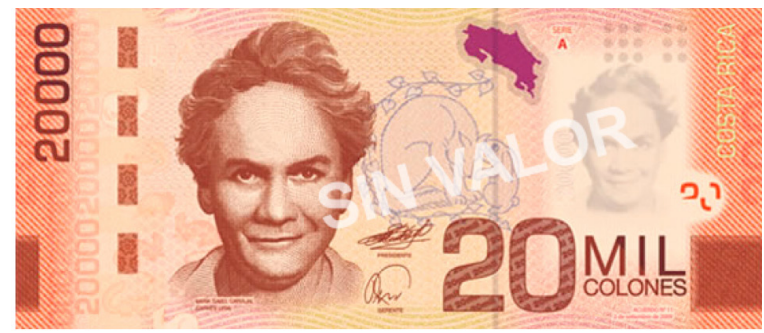

Fuente: Banco Central de Costa Rica, billetes en circulación.
Imagen 24. Reverso del billete de 20000 colones

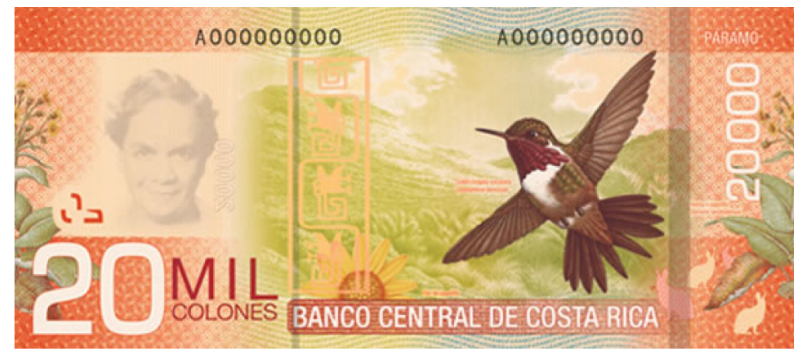

Fuente: Banco Central de Costa Rica, billetes en circulación.

\section{Billete de 50000 colones:}

- Anverso. Plano semántico. Personaje: Ricardo Jiménez Oreamuno. Motivo: Corte Suprema de Justicia.

- Reverso. Plano semántico. Ecosistema: bosque nuboso. Especies destacadas. mariposa Morpho, hongo sombrilla, bromelia. Otros motivos ornamentales: bromelias.

Imagen 25. Anverso del billete de 50000 colones

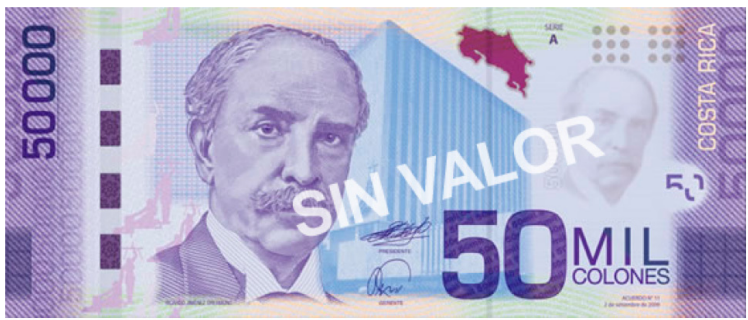

Fuente: Banco Central de Costa Rica, billetes en circulación.
Imagen 26. Reverso del billete de 50000 colones

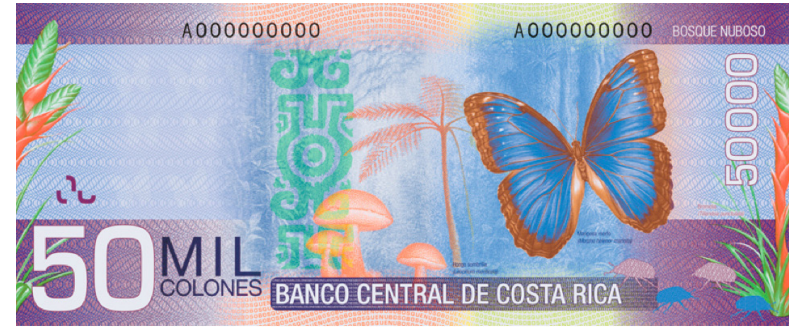

Fuente: Banco Central de Costa Rica, billetes en circulación. 


\section{Plano pragmático general}

En el anverso de los billetes, la representación de los próceres de la patria remite a la lógica individualista, propia de la modernidad, donde la idea del progreso y el nacionalismo del país se encuentra en manos de individuos particulares excepcionales, quienes han hecho aportes a la patria en diferentes áreas de la política y la cultura. Estos individuos y edificaciones se conforman en símbolos del progreso nacional. No existen elementos genéricos que remitan a los aportes colectivos del pueblo, o los ciudadanos, como los obreros o los trabajadores de diferentes áreas que trabajan en el territorio nacional. También, sobre este aspecto destaca el hecho de que solo uno de los seis billetes utiliza como motivo de representación a una mujer. Se podría afirmar que esto revela, también, la mentalidad patriarcal propia de la modernidad, en la que la mujer se encuentra dificultada, por razones sociales y políticas, para poder ocupar espacios, lugares y posiciones particulares de reconocimiento, pues estos se encuentran, generalmente, ocupados por el género masculino ${ }^{11}$.

En cuanto al reverso de los billetes, la representación de diferentes hábitats o ecosistemas presentes de la biodiversidad costarricense evidencia la preocupación por mostrar en los billetes el actual motor de desarrollo económico: la biodiversidad costarricense, como generador del turismo. Se busca representar esta biodiversidad con el fin de explotar la imagen de Costa Rica en el entorno nacional y en el mundo como un destino exótico. Se retoman símbolos como el árbol de Guanacaste en el billete de 1000 colones (también utilizado en otros productos gráficos como el logo del Instituto Nacional de Seguros), que representa la solidez y, a su vez, se trata de un símbolo patrio nacionalista, por ser el árbol nacional. Otro símbolo patrio es el venado, que se encuentra en ese mismo billete.

\section{La ideología y los billetes}

Es fundamental tomar en cuenta el sistema de producción de los signos visuales y la ideología sobre la que se sustentan. Los tiempos actuales se fundamentan en una sociedad basada en el sistema capitalista, en el cual predomina la compra y venta de mercancías. El diseño gráfico, como disciplina, se articula entonces a la lógica comercial del entorno capitalista, caracterizado por la competitividad de las empresas, donde las marcas respaldan los consumibles:

las marcas no son un producto, sino un estilo de vida, constituyen una forma de ser, pensar y sentir. Para lograr este cometido, se apela al nivel pragmático del ícono, en un sentido emotivo, social y simbólico, como sello visual que queda

\footnotetext{
${ }^{11}$ Para un análisis más profundo con respecto a la representación de la mujer en los billetes costarricenses, consultar Chacón (2016).
} 
impreso en la mente del consumidor. Esta potencialidad de los íconos de nuestros días ha garantizado su éxito y posicionamiento y, a la vez, ha creado convenciones y sistematismos propios (Andrade, 2008a, p. 101).

Nuestra época también es la de la publicidad y la rapidez de los procesos, las cuales se pueden visibilizar en las producciones estéticas, como en los diferentes materiales impresos, la web, las redes sociales, los medios de comunicación y el ambiente en general, en un entorno de hibridez cultural. Las producciones visuales responden a las necesidades de rapidez de información y procesos de la vida cotidiana, con el fin de activar el engranaje de producción y consumo de bienes, lo que facilita la sencillez, claridad y velocidad de procesos. El papel moneda, en este sentido, se articula a las necesidades actuales y su uso abarca todos los sectores de la población, como el turismo.

Ahora bien, toda producción artística, en el contexto histórico y cultural actual, se debate entre conservar rasgos originales o dar continuidad a los estilos y convencionales aunados a la ideología dominante. Esta última que asigna a la producción estética un comportamiento, ya sea un estilo o convención, generalmente impuesto y asumido por imitación. En este sentido, el artista y diseñador, en gran medida, depende del arte que se ha producido y conoce. Es decir, para que haya arte debe existir una construcción sígnica que conforme un acuerdo social tácito, algo así como las reglas de juego, que le permiten al espectador decodificarlo y cumplir el objetivo de comunicar.

En los procesos de colonización y transculturación es muy claro cómo se retoman estilos y temáticas particulares, o bien, se combinan o generan nuevos estilos. En este asunto radica nuestro énfasis de estudio, en la medida en la que el proceso colonizatorio genere, o no, una sustitución o sobreposición de estilos, convenciones y temáticas del grupo colonizador en el colonizado, o bien, produzca una mezcla. También en el fenómeno que analizamos está en juego si se sostienen, o no, estilos ajenos a la cultura colonizada, o bien, si se conservan, hibridan, o generan nuevos estilos y temáticas, provenientes de las identidades que, en este caso, conforman lo costarricense.

Tal como lo mencionamos en la sección anterior, los billetes que analizamos retoman rasgos de estilo europeos, que observamos en la trama y los recursos orientados a la simulación del volumen. Las temáticas mostradas en la representación de los próceres de la patria reflejan el pensamiento y los valores de la modernidad. También, encontramos elementos novedosos, específicamente, desde el punto de vista compositivo, así como en la utilización de pequeños elementos decorativos, donde se recurre solo al contorno. Desde el punto de vista temático, la biodiversidad constituye un giro propio, que busca articularse a la imagen de marca país costarricense, en este sentido, se orienta a la lógica del mercado actual. 
El uso de recursos ilustrativos propios del Barroco, Neoclasicismo y Romanticismo en los billetes hasta hoy (que se puede ver en el uso de la trama, las proporciones y profundidad) obedece a la intención de mantener la coherencia propia de la mentalidad colonial, de relacionar los billetes actuales con las convenciones y estilos utilizados en generaciones pasadas. Ciertamente, esto revela una mentalidad de dependencia hacia dichas convenciones estilísticas, por estar legitimado desde la mirada académica del arte europeo del siglo XIX. A la vez, se han dado cambios en los temas representados y en la composición de los billetes, dentro de nuestra lógica, estos cambios obedecen a las nuevas dinámicas ideológicas de la actualidad.

Al analizar los billetes costarricenses, en el marco de la ideología, es necesario contar con alguna información especializada de la época o el lenguaje, para poder entenderlos y darles sentido fuera del análisis estilístico o la experiencia puramente estética que pueda proporcionar. En este aspecto, el lenguaje "no solo es configurado por los contenidos mentales que expresa, sino que influye a la vez en estos contenidos o los configura incluso antes de que estos sean concebidos en el estricto sentido de la palabra" (Hauser, 1975, p. 371). Resulta valioso analizar las palabras que describen la marca país costarricense, para relacionar el diseño de billetes con los términos que constituyen los atributos de este distintivo:

Nuestra Marca País se apalanca en cuatro atributos que la nutren y diferencian. De ellos se desprenden las características más profundas del pueblo tico, nos definen y marcan nuestra esencia.

- Articulador de valor ... plataforma para realizar negocios con oferta diversificada de productos y servicios de calidad mundial ... cultura emprendedora atractiva, disposición de talento humano especializado y cualidades que diferencian los productos y servicios de Costa Rica, favoreciendo la creación de intercambios con altos niveles de satisfacción.

- Autenticidad ... un país auténtico, abierto y cálido de una cultura acogedora y pacífica, receptora al intercambio cultural, anclada en el entendimiento y la capacidad de dar la bienvenida. "Pura vida" expresa de forma concentrada este espíritu singular que solo se vive en Costa Rica.

- Orgullo ... un modo positivo de valorar la herencia histórica, la actualidad y el futuro. La cultura de paz, la preocupación por la educación gratuita y obligatoria, así como a la salud y el cuidado del ambiente, son motivos a través de los cuales el pueblo tico genera una atmósfera de entendimiento, comprensión, superación y visión de futuro.

- Concentrado ... una de nuestras características más potentes. Costa Rica posee un modelo de desarrollo singular en la región, que focaliza sus esfuerzos en el talento humano, la calidad diferenciada. Su ubicación privilegiada, cercana a los 
centros más demandantes de la economía mundial, a la vez que concentra en su territorio una biodiversidad preservada y estudiada (Instituto Costarricense de Turismo, 2017, párrs. 4-7, derivado del reglamento de marca país corporativo).

Cabe destacar que estos valores difieren significativamente de los pregonados hace 50 o 100 años. El diseño de los billetes que circulan en la actualidad y que analizamos, responde a la consecución de los valores que se desean proyectar actualmente, con base en la marca país y en la preocupación por el posicionamiento de esta marca.

Si se concibe la espiritualidad no como un fenómeno estrictamente religioso, sino como la esencia de la manera de pensar propia de un grupo de personas, movidas por un sentido profundo; en la actualidad esta espiritualidad, (observable en el arte gráfico), obedece más bien al orden del mercado ... En la actualidad, el objetivo de las imágenes-icono sigue siendo el envío de un mensaje a las masas, pero ahora su fin es crear una sociedad de consumo capitalista (Andrade, 2008a, p. 103).

\section{Conclusión}

Consideramos necesaria esta revisión, con el fin de aportar a la discusión alrededor de las convenciones y estilos en la ilustración y el diseño. Ello en el marco de la colonialidad del entorno latinoamericano y, específicamente, el costarricense, en función de las identidades culturales que nos conforman como pueblo. La mirada exótica, desde lo ajeno y la otredad, presentes en la ilustración científica, resulta conveniente desde el posicionamiento del extranjero que visita el país. Este encuentra en la colección de billetes coherencia visual con la marca-país, la vemos enfatizada en los billetes actuales, en la exotización del paisaje, la ilustración botánica y los elementos de fauna. En el análisis de la nueva familia de billetes costarricenses encontramos otra identidad cultural costarricense. Este es el caso de la indígena, la cual queda reducida a una mirada arqueológica (solo presente en los sellos de seguridad utilizados), que destacamos en la Imagen 27.

La menor presencia de elementos indígenas en los billetes actuales, impresos en tamaño pequeño, con tintas iridiscentes semitransparentes, demostrada tras esta reflexión, en el análisis semiótico de los billetes, nos lleva a valorar hasta qué punto ha existido imposición de estilos europeos. Así como una sobreposición o anulación de formas de diseño, como la precolombina que, aun siendo propia o más cercana a nuestra historia por no ser europea, ha estado sumida en la deslegitimación y, por ello, se ha representado poco y por tanto tiempo así ha sido y sigue siendo de esta manera ${ }^{12}$.

\footnotetext{
${ }^{12}$ Investigaciones como la de Henry Vargas (2015), logran su cometido al sacar, de una vez por
} 
Imagen 27. Sellos de seguridad con motivos precolombinos en la nueva familia de billetes costarricenses

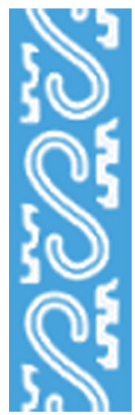

2000

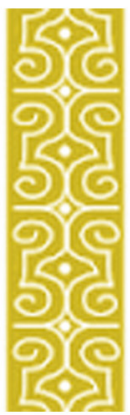

5000

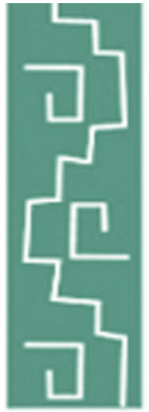

10000

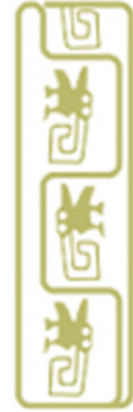

20000

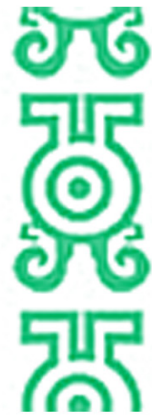

50000

Fuente: Elaboración propia a partir de la imagen de Jessenia Araya Vega (2012).

También, queda demostrado que, en el papel moneda de una Costa Rica occidentalizada y capitalista, encontramos lo indígena, en menor presencia, junto a lo europeo. Todo ello convive y forma parte de las prácticas locales. No encontramos en la revisión de billetes ninguno que abordara las identidades negras o chinas costarricenses, las cuales también conforman lo nacional. Consideramos valiosa la reflexión realizada sobre el uso del lenguaje, como instrumento analítico de las producciones visuales y su relación con la ideología. Finalmente, interesa aportar a la reflexión la pregunta: ¿qué prácticas de diseño podrían ser más válidas e integradoras en el entorno actual costarricense?, o más importante aún, plantearnos la apertura de la academia y la producción visual en Costa Rica, en términos de flexibilidad y comprensión de nuestras identidades culturales, nuestra multiculturalidad y complejidad. Todo esto, con el fin de encontrar formas de diseño propias que resulten más integradoras. Ciertamente, nuestra riqueza cultural se encuentra conformada por lo indígena, lo europeo, lo negro, lo chino y, quizá, otros orígenes. Es un reto que, desde una actitud decolonial, el diseño costarricense genere propuestas desde adentro, no por copia o imposición. Porque, al igual que la Bauhaus, luego de 100 años de su fundación y desde el contexto diferenciado de un entorno latinoamericano, nos atrevemos a vislumbrar una "nueva visión" del diseño gráfico en Costa Rica.

todas, el diseño precolombino de la esfera de la arqueología y nos permite darnos cuenta de su profundidad, aportes y trascendencia. Además, muestra que, a nivel técnico y de diseño, ciertamente constituye toda una academia desde el punto de vista visual y también forma parte fundamental de nuestra historia. 


\section{Referencias}

Andrade, G. (2008a). Los procesos cognitivos y sociales relacionados con el dibujo artístico: imágenes y estereotipos en la era de la imagen (tesis para optar por el grado de Máster en Artes). Universidad de Costa Rica, San José, Costa Rica.

Andrade, G. (2008b). Convencionalismos y popularidad: Iconos de los tiempos modernos. El artista, 5, 96-104. Recuperado de http://www.redalyc.org/articulo.oa?id=87411107008

Araya, J. (28 de junio de 2012). Patrones de los sellos usados en los billetes costarricenses [Imagen]. Recuperado de: http://visual744.blogspot.com/2012/06/?view=classic

Banco Central de Costa Rica. (8 de agosto de 2013). Conozca la nueva familia de billetes de Costa Rica [YouTube]. Recuperado de https://www.youtube.com/watch?v=YaBKXA-7HLI

Banco Central de Costa Rica. (2019). Billetes y Monedas. Billetes en circulación. Recuperado de https://www.bccr.fi.cr/seccion-billetes-y-monedas/billetes-en-circulaci\%c3\%b3n

Banco Central de Costa Rica. (2019). Billetes y Monedas. Billetes retirados de circulación. Recuperado de: https://www.bccr.fi.cr/seccion-billetes-y-monedas/billetes-en-circulaci\%C3\%B3n/billetes-retirados-de-circulaci\%C3\%B3n

Barrionuevo, F. (1997). Catálogo del Centenario de La Escuela Nacional de Bellas Artes, Escuela de Artes Plásticas, 1897-1997 (volumen 1). San José: Museo de Arte Costarricense y Escuela de Artes Plásticas de la Universidad de Costa Rica.

Carranza, J. (2012). Historia de los billetes de Costa Rica, 1858-2012 (1 ed.) San José: J. Carranza A.

Castro, J. (2014). Análisis estético, iconológico e iconográfico de la nueva familia de papel moneda de Costa Rica 2009-2012 y sus antecendentes (tesis maestría académica en artes visuales). Universidad de Costa Rica, San José, Costa Rica.

Chacón M. \& Alvarado, I. (2001). Gráfica en el papel moneda; 1858-1936. San José, Costa Rica: Fundación Museos del Banco Central de Costa Rica.

Chacón, M. (2016). La figura femenina en las monedas de Costa Rica (1845-2016). San José: Fundación Museos del Banco Central de Costa Rica.

Clay Irving Collection. (s.f.). Clay Irving Collection Costa Rica [Imagen]. Recuperado de http:// www.panix.com/ clay/currency/CR-236.jpg

Colnet. (s.f.) Cátalogo de billetes. Recuperado de https://colnect.com/es/banknotes/banknote/2959-500_Colones-2000_50th_Anniversary_of_Banco_Central_de_Costa_Rica_ Issue-Costa_Rica

ESCENA. Revista de las artes, 2020, Vol. 79, Núm. 2 (enero-junio), pp. 99-125 
Temas, convenciones y estilos en el diseño de la nueva familia de billetes

Artículos costarricenses 2009-2019, como expresión de ideología y colonialidad

Depositphoto. (s.f.) Moneda costarricense [Imagen]. Recuperado de https://sp.depositphotos. com/97583818/stock-photo-coin-costa-rica.html

Depositphoto. (s.f.). Una moneda de colón costarricense [Imagen]. Recuperado de https:// sp.depositphotos.com/23807147/stock-photo-one-costa-rican-colon-coin.html

Fernández, S. (2014). El arte del cajista en las portadas barrocas neoclásicas y románticas (1777-1850). México: Universidad Autónoma de México.

Ferrero, L. (2004). Sociedad y arte en la Costa Rica del siglo 19. San José, Costa Rica: Editorial EUNED.

Garrido, B. (2015). Colonialismo, colonialidad, modernidad. Revista de Artes y Humanidades Artium, 8, Recuperado de https://www.academia.edu/10016978/COLONIALISMO_COLONIALIDAD_Y_MODERNIDAD

Goodfellow, C. \& Vargas, S. (2014). Grafitica: Gráfica popular costarricense (1ª ed). San José: Roger Union Printing.

Gruzinski, S. (1991). La colonización de lo imaginario. Sociedades indígenas y occidentalización en el México colonial español. Siglos XVI-XVIII (trad. Jorge Ferreiro). México: Fondo de Cultura Económica.

Gruzinski, S. (1994). La guerra de las imágenes. De Cristóbal Colón a "Blade Runner". México: Fondo de Cultura Económica.

Hauser, A. ([1964] 1975). Teorías del arte, tendencias y métodos de la crítica moderna (edición especial). Londres: Guadarrama.

Hill E. (2010). Relatos en rojo y negro. Historias pictóricas de aztecas y mixtecos. México: Fondo de Cultura Económica.

Hurtado, A. (2017). Figurines de moda y formación del gusto de las élites costarricenses a finales del siglo XIX (1889-1896). ESCENA. Revista de las artes, 77(1), 4-30. DOI 10.15517/ES.V7711.30110

Instituto Costarricense de Turismo. (2017). Marca país. Esencial Costa Rica [página web]. Recuperado de https://www.ict.go.cr/es/servicios-institucionales/guias-de-turismo/2-

Molina, I. (2005). Costarricense por dicha. Identidad nacional y cambio cultural en Costa Rica durante los siglos XIX y XX. San José: Editorial de la Universidad de Costa Rica.

Montero, C. (2015). Arte costarricense: 1897-1971. San José: Editorial de la Universidad de Costa Rica.

Oviedo, M. \& Santamaría, L. (2015). Mercato Culturale: El nacimiento de la ornamentación de un Coliseo. Diálogos: Revista electrónica de historia, 16(2), 27-57. DOI: 10.15517/ DRE.V16I2.16677

ESCENA. Revista de las artes, 2020, Vol. 79, Núm. 2 (enero-junio), pp. 99-125 
Parkinson, L. (2011). La Mirada exuberante. Barroco Novomundista y literatura latinoamericana. México, D.F.: Universidad Nacional Autónoma de México/Bonilla Artigas Editores/ Editorial Iberoamericana/Editorial Vervuert.

Quijano, A. (2014). Cuestiones y horizontes. Antología esencial de la Dependencia Histórico Estructural de la Colonialidad/Descolonialidad del poder. Buenos Aires: Editorial CLACSO.

Raabe, L. (2012). Los antiguos yesos de Bellas Artes. Káñina, Revista de Artes y Letras, 36(Extraordinario), 95-98.

Raabe, L. (2017). La Escuela Nacional de Bellas Artes 1897-1940. En Catálogo de vaciados en yeso y láminas litográficas. Escuela de Artes Plásticas Universidad de Costa Rica. San José: Master Litho.

Sánchez, J. (2013). Las láminas de dibujo de la Escuela Nacional de Bellas Artes. Revista Humanidades, 3, 1-10

Sánchez, J. (2016). Arte y Currículum: La Escuela de Artes Plásticas de la Universidad de Costa Rica (1897-2015). Revista Humanidades, 6(1) 1-40. DOl: https://doi.org/10.15517/h.v6i1.24963

Segato, R. (2015). Crítica de la colonialidad en ocho ensayos. Y una antropología por demanda. Buenos Aires: Editorial Prometeo.

Segre, E. (2007). Intersected identities. Strategies of visualization on Nineth and Twentieth Century Mexican Culture. Estados Unidos: Berghahn Books.

Solórzano, J. (2017). La construcción teórica de la categoría arte precolombino en Costa Rica 1887-2010 (tesis de maestría académica en artes con énfasis en artes visuales). Universidad de Costa Rica. San José, Costa Rica.

Spitta, S. (1995). Between Two Waters. Narratives of transculturation in Latin America. Texas: Rice University Press.

Ucoin. (s.f.). Catálogo de monedas [Imagen]. Recuperado de https://es.ucoin.net/coin/costa_rica-5-centimos-1951/?tid=18997

Ulloa, E. (2017). Ut picture poësis. Los fundamentos teóricos de la academia. En Catálogo de vaciados en yeso y láminas litográficas. Escuela de Artes Plásticas Universidad de Costa Rica. San José: Master Litho.

Vargas, J., Gómez, J. \& Chacón, M. (2009). Plantas y animales en la numismática costarricense (1 ${ }^{\mathrm{a}}$. ed). San José, Costa Rica: Fundación de Museos del Banco Central.

Vargas, S, \& Goodfellow, C. (2014). GRAFITICA: Gráfica Popular Costarricense. San José: Roger Union Printing.

Zapelli, G. (2003). La huella creativa. San José: Editorial de la Universidad de Costa Rica. 